\title{
A new look at board interlocking: evidence from corporate social networks
}

\author{
Cristian Baú Dal Magro 1 \\ Roberto Carlos Klann 2 \\ 1 Universidade Comunitária da Região de Chapecó / Programa de Pós-Graduação em Ciências Contábeis e Administração, \\ Blumenau / SC - Brazil \\ ${ }^{2}$ Universidade Regional de Blumenau / Programa de Pós-Graduação em Ciências Contábeis, Blumenau / SC - Brazil
}

The study aims to evaluate the interconnection structures by members of the Board of Directors with political and financial expertise of companies listed in the Brazilian stock market B3. The sample consisted of 2,474 observations in the period from 2010 to 2015. It is suggested by the Agency Theory that board interlocking (BI) for financial expertise can help in corporate monitoring and mitigates the agency's conflicts. On the other hand, BI by political expertise can maximize opportunistic behavior. In the view of Resource Dependency Theory, BI for financial expertise can assist companies in attracting financial resources, while BI for policy expertise can maximize results through more lucrative contracts and advantages offered by policymakers. It is concluded that the systematization of BI by different expertise can be used in future research to explain corporate strategies, decisions, and phenomena, as well as to evaluate the causes and effects of such structures in the management of organizations.

Keywords: board interlocking; board of directors; political expertise; financial expertise.

\section{Novo olhar ao board interlocking: evidências a partir das redes sociais corporativas}

Este estudo teve por objetivo avaliar as estruturas de interligações pelos membros do conselho de administração (CA) com expertise política e financeira de empresas listadas na B3. A amostra foi composta por 2.474 observações no período de 2010 a 2015. Por meio da Teoria da Agência, sugere-se que o board interlocking (BI) pela expertise financeira pode auxiliar o monitoramento corporativo e servir como mitigador dos conflitos da agência. Por outro lado, o BI pela expertise política pode maximizar o comportamento oportunista. Na visão da Teoria da Dependência de Recursos, o BI pela expertise financeira pode auxiliar as empresas na captação de recursos financeiros, enquanto o BI pela expertise política pode maximizar os resultados mediante contratos mais lucrativos e vantagens oferecidas pelos políticos. Conclui-se que a sistematização do BI pelos diferentes tipos de expertise pode ser utilizada em futuras pesquisas para explicar as estratégias, as decisões e os fenômenos corporativos, bem como para avaliar as causas e os efeitos de tais estruturas na gestão das organizações.

Palavras-chave: board interlocking; conselho de administração; expertise política; expertise financeira.

\section{Nueva mirada al board interlocking: evidencias a partir de las redes sociales corporativas}

El estudio tiene como objetivo evaluar las estructuras de interconexiones entre los miembros del Consejo de Administración (CA) con experiencia política y financiera de empresas que cotizan en la B3. La muestra se compuso de 2.474 observaciones en el período 2010-2015. Por medio de la Teoría de la Agencia, se sugiere que el board interlocking (BI) por la experiencia financiera puede auxiliar al monitoreo corporativo y servir como mitigador de los conflictos de la agencia. Por otro lado, el BI por la experiencia política puede maximizar el comportamiento oportunista. En la visión de la Teoría de la Dependencia de Recursos, el BI por la experiencia financiera puede auxiliar a las empresas en la captación de recursos financieros, mientras que el BI por la experiencia política puede maximizar los resultados mediante contratos más lucrativos y ventajas ofrecidas por los políticos. Se concluye que la sistematización del BI por las diferentes experiencias puede ser utilizada en las investigaciones futuras para explicar las estrategias, decisiones y fenómenos corporativos, así como para evaluar las causas y los efectos de tales estructuras en la gestión de las organizaciones.

Palabras clave: board interlocking; consejo de administración; experiencia política; experiencia financiera. 


\section{INTRODUCTION}

The characteristics of the board of directors partially determine the organizational environment, strategy, and financial performance. Therefore, the socialization of board members becomes a determining factor of operations and processes (Pearce \& Zahra, 1992). The social interaction of board members may be a preponderant factor in modifying organizational ideas, attitudes, and decisions (Borgatti \& Foster, 2003; Davis, 1991; Elouaer-Mrizak \& Chastand, 2013; Haunschild, 1993; Ribeiro \& Colauto, 2016; Wasserman \& Faust, 1994).

The social networks established among board members are known as board interlocking (BI), particularly when a firm's board member simultaneously occupies the seat on the board of another company (Fich \& White, 2005; Mizruchi, 1996). BI occurs with the overlapping of individuals on more than one board of directors creating a network that enables sharing knowledge and experiences (Shropshire, 2010).

According to $\mathrm{Mol}$ (2001), BI is beneficial to obtain resources and clients, as well as in the diffusion of methods that have been effective in other companies. Haniffa and Cooke (2002) and Kim and Cannella (2008) mention that BI can improve corporate monitoring and reduce agency conflicts. On the other hand, Bizjak, Lemmon, and Whitby (2009) state that BI expands agency conflicts, while Dhaliwal, Naiker, and Navissi (2010) claim that it impairs corporate monitoring.

Based on the agency theory and resource dependency theory, it is possible to observe that BI can include individuals who have specific interests and expertise, which can cause the transmission of different types of information through the board. Thus, differentiating the individuals that form BI can help identify the agency conflicts and enable the discovery of alternative ways to obtain scarce resources.

The knowledge gained from other institutional links, professional experiences, and academic training means each board member has a type of expertise that can modify their decisions and attitudes in the dissemination of corporate information and decisions. Therefore, when there is simultaneous participation of a member with a specific expertise in two or more boards, the interests arising from such expertise can influence the decisions, behaviors, and attitudes of organizations.

BI can be understood from the perspectives of both political and financial expertise. The latter, derived from the board member's background with banks and financial institutions, whereas the former is derived from the board members who have held positions in the federal, state or municipal legislative and executive branches, as well as those with positions in government-controlled companies (Boubakri, Cosset, \& Saffar, 2008; Camilo, Marcon, \& Bandeira-de-Mello, 2012; Chaney, Faccio, \& Parsley, 2011).

BI research has advanced regarding the way this phenomenon affects businesses. Some examples are the studies relating BI to executive compensation (Wong, Gygax \& Wang, 2015), corporate performance (Camilo et al., 2012), investment options, mergers and strategic decisions (Bizjak et al., 2009), earnings smoothing (Ribeiro \& Colauto, 2016) and earnings management practices (Chiu, Teoh, \& Tian, 2013). However, there are still research gaps resulting from studies that fail in specifying the elements within the BI and considering the nature and behavioral processes of the connected individuals (Gulati \& Westphal, 1999). Therefore, the research question is: 
- What is the interconnection framework involving board members with political and financial expertise in firms listed in the Brazilian stock exchange B3?

The objective of this study, therefore, was to examine and understand this framework in order to answer the research question.

The proposal of new systematics for BI assessment may contribute to theoretical challenges not yet addressed by Agency and Resource Dependency Theories, by treating social relations as a fundamental unit of analysis rather than ontological actors frozen in space and time (Aguilera \& Jackson, 2010). The Brazilian economy has undergone a period of turbulence due to political scandals, with Operation Car Wash gaining prominence in 2014. The operation has resulted in successive arrests and accusations that have made headlines worldwide. Examining BI as an individualized unit of analysis of board members with political expertise, is a unique opportunity for understanding corporate practices and decisions, especially in times of economic and political imbalance.

The effects of political connections can be stronger in environments where the government exercises more control (Agrawal \& Knoeber, 2001), in companies operating in an environment with a weak legal system, a higher level of corruption and less transparency (Faccio, 2006). Political connections prevail in countries with less judicial independence (Boubakri et al., 2008), making Brazil an ideal context to study.

In addition, when considering that fundraising by Brazilian companies occurs more frequently through financial institutions, unlike countries with more developed capital market, studying BI formed by financial expertise may prove to be a fertile field for understanding companies funding sources.

This study challenges the conventional BI approach. The practical contribution here is based on the view that the shareholders, investors, and market analysts need to understand better the sociological aspects of the firms. This study recognizes that BI operates through underlying forces, and the assumption is that it is possible to capture the interests around the formation of BI. The attempt is to provide managers, directors, auditors, analysts, regulators, investors, and other stakeholders, with more comprehensive sociological information on this issue, which can help future studies to unveil new causes and effects of the board members in the organization's management.

\section{AGENCY AND RESOURCE DEPENDENCE THEORIES IN THE CAUSALITIES OF BOARD INTERLOCKING}

Additional sociological insight into the economic perspective of the agency theory can be useful to broaden the explanatory factors of agency conflicts and corporate monitoring exercised by board members. This is because the board of directors is composed of individuals who have a vast network of relationships with distinct corporations, making sociological insight stand out from the economic (Fama \& Jensen, 1983).

Jensen and Meckling (1976) recognized, through agency theory, that human attributes of limited rationality and managerial opportunism are affected by the coexistence and channels of communication between individuals. The authors expand the discussion on socialization later, by inferring that 
intermediaries such as politicians, banks, insurance companies, and pension funds often hold financial rights over corporate assets (Jensen \& Meckling, 1978).

Understanding contextual antecedents and social relationships that influence the specific manifestations of agency problems improve explanations about structure and monitoring costs, which also vary to the detriment of different socialization contexts (Aguilera \& Jackson, 2010; Fligstein \& Freeland, 1995). According to Boubakri, Guedhami, Mishra, and Saffar (2012), agency problems enable political affiliates to derive political benefits over other stakeholders by increasing their incentives for minority shareholders expropriation.

In addition, from the perspective of resource dependency theory, the board of directors also relates to the maintenance of organizational resources (Gales \& Kesner, 1994; Hillman, Cannella, \& Paetzold, 2000; Pfeifer, 1972; Salancik \& Pfeffer, 1978). This theory deals with the board of directors' capacity to provide resources for the company, and the organization's strengths and weaknesses limit or facilitate the acquisition of the resources (Wernerfelt, 1984). Mizruchi (1996) notes that corporate social networks among board members can bring benefits that involve: a) reducing uncertainty in obtaining external resources (Salancik \& Pfeffer, 1978); b) guaranteeing critical resources; c) access to strategic opportunities (Eisenhardt \& Schoonhoven, 1996); and d) benefits of legitimacy (Galaskiewicz, 1985).

Resource dependency theory suggests that the interaction between firm and environment is fundamental for the strategies conception that captures vital resources for the achievement of results (Hillman \& Hitt, 1999). In this sense, firms seek to strengthen ties with the environment in order to preserve the essential resources for value creation (Agrawal \& Knoeber, 2001; Hillman \& Keim, 1995; Johnson \& Mitton, 2003).

Therefore, the reduction of uncertainties about the resources required for organizational activities can occur through the communication channels created by board members, which in turn provides preferential access to essential elements outside the company, reducing contingencies and transaction costs (Salancik \& Pfeffer, 1978). On the other hand, the organization interdependence with its environment can affect its autonomy and establish uncertainties about the future (Bazerman \& Schoorman, 1983).

The composition of the board of directors embraces insiders and outsiders who have different intellectual capitals, such as lawyers, engineers, bankers, politicians, community leaders, among others. These professionals tend to disseminate guidelines that differ according to their expertise, stemming from knowledge, experience, and skills (Gales \& Kesner, 1994).

Camilo et al. (2012) discussed whether the firm's social ties with the government could reduce resource dependence and achieve positive effects on performance. The central focus of the resource dependency theory was to demonstrate the importance of politicians on board of directors of private companies in obtaining scarce resources and expanding the interrelation with unreachable environments. However, the authors did not establish interconnection between BI and the presence of politicians on the board of directors.

Both agency and resource dependency theorists examined the monitoring and resource allocation functions, respectively, contributing to an incomplete understanding of the BI effects on organizations. 
Each perspective has been limited to study particular antecedents, and seen separately, both approaches provide an incomplete understanding of what contributes to resource provisioning and organizational monitoring (Hillman \& Dalziel, 2003).

Thus, a common theoretical understanding can provide support for broadening board of directors' social relations on the observation of the dynamics between board members with specific expertise (political and financial expertise, in this case). To satisfy the contradictions of Bowen, Rajgopal and Venkatachalam (2008), Bizjak et al. (2009), Dhaliwal et al. (2010), Hoitash (2011), Chiu et al. (2013), Ribeiro and Colauto (2016), and Cunha and Piccoli (2017), this research added the view that BI does not transmit homogeneous information and that this difference can come from the expertise of boards members that form the BI.

Therefore, we add the financial connection vision to BI, studied by Markarian and Parbonetti (2009), and the political connection researched by Chaney et al. (2011), Batta, Sucre-Heredia and Weidenmier (2014), and Bona-Sánchez, Pérez-Alemán, and Santana-Martín (2014). These studies, however, only addressed the existence of companies with board members that have political and financial expertise, and did not cover the perspectives observed in a BI formed by such individuals.

\section{BOARD INTERLOCKING AND POLITICAL AND FINANCIAL EXPERTISE}

BI refers to the social relations created between two or more companies through the inclusion of the same professional on their boards of directors (Fich \& Shivdasani, 2006; Fich \& White, 2005; Mizruchi, 1996). BI can encourage imitation not only of conscious choices but also of malicious socialization processes (Galaskiewicz \& Wasserman, 1989). Complementarily, Loderer, and Peyer (2002) comment that the practice of $\mathrm{BI}$ is the root of many evils.

Devos, Prevost, and Puthenpurackal (2009) suggest that BI can compromise effectiveness in corporate monitoring. Studies indicate that the presence of interconnected members (board interlocking) is indicative of poor governance and may have negative consequences for group thinking (Chiu et al., 2013; Cunha \& Piccoli, 2017; Fich \& Shivdasani, 2006; Ribeiro \& Colauto, 2016).

Board members connected to companies that usually adopt an opportunistic stance can distort ethical behavioral (Borgatti \& Foster, 2003; Connelly \& Slyke, 2012; Harris \& Helfat, 2007). Burris (2005) comments that BI has become the target of criticism and praise, and to evaluate its effects, it is necessary to question the purposes and reasons for its formation (Santos, Silveira, \& Barros, 2012).

The studies that address BI have observed only the social connections, without segregating the different member's expertise that has these links. We highlight the studies by D'Aveni and Kesner (1993) and Cai and Sevilir (2012), which addressed the BI influence in organizational mergers and acquisitions. Kim (2005) and Santos et al. (2012) observed changes in the performance and market value of organizations. Based on this evidence, there is a need to observe the BI formation in a less generalized way, entering the specifics of the connected members.

In this sense, a company can benefit by adding a government representative to the board of directors, but this may incur the government having access to sensitive company information, 
which may influence its strategic decisions (Okhmatovskiy, 2010). Faccio (2006) pointed out that the political connection may privilege organizations with a differentiated treatment in the relationship with the government, including lower taxation, preferences in contracts, and tighter regulation of competitors.

On the other hand, companies connected with politicians are under more public scrutiny and subject to more extensive monitoring controls than unconnected companies (Chaney et al., 2011). However, market players believe that the firm's approach to government reduces uncertainties, and that the economic agents who aim for a particular position are providers of relationships with influential political institutions (Camilo et al., 2012).

The political connection comprises the participation of individuals who are connected to the government on the board of directors of private companies and, if these individuals participate on the board of directors of several firms simultaneously, it may be considered board interlocking by the political expertise.

The BI for political expertise is formed through social network such as in other BI. The difference lies with the political board members who are at the same time on the board of directors of other companies (Batta et al., 2014; Braam, Nandy, Weitzel, \& Lodh, 2015; Camilo et al., 2012; Chaney et al., 2011; Guedhami, Pittman, \& Saffar, 2014; Ramanna \& Roychowdhury, 2010).

According to Faccio (2006), the political connection occurs when at least one shareholder, with at least $10 \%$ of voting shares, or one executive (president, vice president, board member), is also a member of parliament, minister, or is related to a political party. It can also be expressed by former politicians who occupy seats on the board of directors of private firms (Boubakri et al., 2008; Camilo et al., 2012, Chaney et al., 2011, Faccio, 2006).

The political connection may also occur when a board member has held a position in the Senate, in the Chamber of Deputies or on the board of organizations with links in government or appointed for public roles (Camilo et al., 2012; Chaney et al., 2011; Faccio, 2006).

The BI by financial expertise can be observed in a similar way to the one observed in the social and political expertise. The difference lies in the financial advisor's specification, also connected to the organization's board (Davis \& Mizruchi, 1999; Elouaer-Mrizak \& Chastand, 2013; Güner, Malmendier, \& Tate, 2008; Markarian \& Parbonetti, 2009; Stearns \& Mizruchi, 1993).

Loderer and Peyer (2002) comment that the financial connections depend on the appointment of bankers to occupy the board of directors of non-financial companies simultaneously. The board members of non-financial corporations often represent the business relationships maintained with financial institutions and therefore, because of their central location in the BI, and their unique role in the economy, banks are privileged in the type of information they have access to.

Often, bankers get a position on the board of directors of companies facing financial difficulties. Mizruchi and Stearns (1988) and Stearns and Mizruchi (1993) mentioned the tendency of corporations to appoint bankers on their boards, especially when solvency and profitability are low and when their capital requirements correspond to macroeconomic conditions, such as a decrease in interest rates.

The literature points out some reasons for the financial connection: by inserting a professional linked to a financial institution on the board of directors, the company expects to have easy access to 
capital. On the other hand, the financial institution's advisor may interfere in the company's operational and strategic decisions (Stearns \& Mizruchi, 1993).

Firms benefit from the presence of bankers on the board of directors, such as financial expertise, financial advice, and new investments (Byrd \& Mizruchi, 2005). However, in addition to monitoring and providing financial expertise, bankers can behave opportunistically, given their, often conflicting, roles (Markarian \& Parbonetti, 2009).

Finally, we have established that board interlocking, formed by individuals with social expertise, would be free of some political interests and financial institutions and, therefore, this proxy would not have inseparable behaviors. However, there is a limitation that is, even when establishing control of political and financial expertise; it is not possible to say that the BI of social expertise is isolated from other factors.

\section{METHODOLOGY}

This study has a descriptive, documentary, and quantitative approach. The period of analysis comprised six years, from 2010 to 2015. The population considers the public companies listed in B3 in December 2015, which was necessary for the availability of administration report and the reference form of all companies. The study started from the listed companies in December 2015, later segregating those listed in each year of analysis, considering the data for establishing the networks analysis among the directors.

Then, for the sample composition, some adjustments to the companies that represent the research population were made. Table 1 shows in detail the exclusion of companies.

\section{TABLE 1 SAMPLE COMPOSITION}

\begin{tabular}{|c|c|c|c|c|c|c|}
\hline Companies & 2010 & 2011 & 2012 & 2013 & 2014 & 2015 \\
\hline (+) B3 Listed & 434 & 434 & 434 & 434 & 434 & 434 \\
\hline (-)No data or information available & $(40)$ & $(40)$ & (28) & (13) & (09) & --- \\
\hline (=) Sample used in network analysis & 394 & 394 & 406 & 421 & 425 & 434 \\
\hline
\end{tabular}

Source: Elaborated by the authors.

Table 1 shows the standardization of research population by those companies listed in B3 in 2015 also listed in previous years. Subsequently, companies that in previous years were modified by mergers, divisions and acquisitions were excluded and, therefore, did not present data availability. Thus, 40 companies from 2010 and 2011, 28 companies from 2012, 13 companies from 2013, and nine 
companies from 2014 were excluded. Finally, the sample consisted of a total of 2,474 observations during the six years of analysis.

First, the BI treatment did not discriminate the political and financial expertise, and the names of directors were written in a spreadsheet with their respective companies. Subsequently, the directors who occupied seats on the board of directors of several companies at the same time were identified, thus creating a matrix that determines the connections of the companies based on their directors.

The matrix in Microsoft Excel $^{\varpi}$ was used in the UCINET software to measure the degree of the centrality indicator (direct links) and the centrality indicator of betweenness (indirect links), without distinction of the political and financial expertise.

Next, the BI was elaborated considering three types of expertise a) social b) political, and c) financial. The BI for social expertise sought to improve the view of the studies of Chiu et al. (2013), Shu, Yeh, Chiu, and Yang (2015), Cai, Dhaliwal, Kim, and Pan (2014), Ribeiro and Colauto (2016), and Cunha and Piccoli (2017). In order to establish the variable, the same premises of the previous studies were used. However, the board members with political or financial expertise for network formation and centrality indicators were excluded. Therefore, taking in account that BI refers to the social relations created between two or more companies through the inclusion of the same professional on their boards of directors (Fich \& Shivdasani, 2006; Fich \& White, 2005; Mizruchi, 1996), if this professional does not have political or financial expertise, we considered it as a social BI.

The BI for political expertise was established by observing the curriculum of each board member, identifying those who held some political office at municipal, state or federal level (Boubakri et al., 2008; Chaney et al., 2011; Faccio, 2006).

Robustness tests were applied to generate more reliability for the BI variable through the political connection. The first added the state-owned companies' directors to the political expertise. The second test added the board members who donated for the 2016 election campaign.

The choice for the 2016 election was made because of Law 13165/2015, which provides that legal entities cannot donate to electoral campaigns, increasing the importance of donations from individuals. Board members who contributed in the 2016 election campaign were identified by the number of register with the Brazilian revenue agency (CPF) of each board member in the 2016 Federal General Election (2016).

As for the BI for financial expertise, it was also established by reading the curriculum of each board members. Those belonging to the board of directors or having a management position in financial institutions were considered as members with financial expertise (Byrd \& Mizruchi, 2005; Güner et al., 2008; Markarian \& Parbonetti, 2009).

A spreadsheet was then prepared with the names of the directors and their companies. Next, the directors who simultaneously occupied seats on the board of directors of other organizations through the elaboration of matrices with the interconnections. Finally, the spreadsheet created in Microsoft Excel $^{\circledR}$ in the UCINET software was used to establish centrality (direct linking) and betweenness (indirect) of members with social, political, and financial expertise.

The study data collection is ex post facto, when the variables are not under the researcher's direct control, instead, we define them after the occurrence of the event of interest (Ryan, Scapens, \& Theobald, 2002). The data was collected from documents, based on different sources, shown in Table 2. 


\section{TABLE 2 SOURCES USED FOR DATA COLLECTION}

\begin{tabular}{|c|c|c|}
\hline Variable & Acronyms & Source \\
\hline Board interlocking (BI) & (LDBI); (LIBI) & $\begin{array}{l}\text { a) Reference Form - B3 } \\
\text { b) Software UCINET }\end{array}$ \\
\hline Social Expertise (ES) & (LDES); (LIES) & $\begin{array}{l}\text { a) Reference Form - B3 } \\
\text { b) Software UCINET }\end{array}$ \\
\hline & $\begin{array}{c}\text { (LDEP); }(\text { LIEP) (LDEPE); } \\
\text { (LIEPE) }\end{array}$ & $\begin{array}{l}\text { a) Reference Form - B3 } \\
\text { b) Software UCINET }\end{array}$ \\
\hline Policital Expertise (EP) & (LDEPD); (LIEPED) & $\begin{array}{l}\text { a) Reference Form - B3 } \\
\text { b) Superior Electoral Court - Disclosure of Election } \\
\text { Candidatures and Accounts (Federal General Election } \\
2018,2018 \text { ) } \\
\text { c) Software UCINET }\end{array}$ \\
\hline Financial Expertise (EF) & (LDEF); (LIEF) & $\begin{array}{l}\text { a) Reference Form - B3 } \\
\text { b) Software UCINET }\end{array}$ \\
\hline
\end{tabular}

Source: Elaborated by the authors.

LDBI = direct board interlocking tie; LIBI = indirect board interlocking tie; LDES = direct link through social expertise; LIES = indirect link through social expertise; LDEP = direct link for political expertise; LIEP = indirect link for political expertise; LDEPE $=$ direct link for political and state expertise; LIEPE = indirect link for political and state expertise; LDEPED = direct link for political, state and campaign donation expertise; LIEPED = indirect link for political, state and campaign donation expertise; LDEF = direct link for financial expertise; LIEF = indirect link for financial expertise.

First, data was analyzed by the proportion of companies with board members for the different types of expertise obtained through direct and indirect ties from corporate social networks. In addition, the descriptive statistics of BI by the different expertise were elaborated, in which the average, median, standard deviation, minimum and maximum values of direct (degree) and indirect (betweenness) indicators of each BI expertise are presented.

\section{RESULTS AND DISCUSSION}

First, Table 3 presents the results concerning the number of companies with some direct or indirect connection to $\mathrm{BI}$ according to each evaluated expertise.

Panel A of Table 3 shows that, on average, 74.82\% (40.22\%) of the companies had some direct (indirect) connection between the directors. The years with the highest percentage of direct connections occurred in 2010 and 2014, with 77.92\% and 75.53\% of companies, respectively. The indirect connections occurred in a higher proportion in 2010 and 2012 , with $42.13 \%$ and $42.12 \%$, respectively.

It is possible to observe that the companies listed in B3 have used BI, however, it is necessary to know what the purpose of these formations was. To find out, observations of the systematized expertise by the members that are part of the social connections by the board of directors was undertaken. Panel B shows the number of direct and indirect BI links considering only the board members with financial expertise. The systematization presents feasibility for possible causes and effects of statistical analysis in the organization's management since we found an average of $38.80 \%$ of companies with such specifics within their board of directors (12.37\% with indirect links). 
RAP | A new look at board interlocking: evidence from corporate social networks

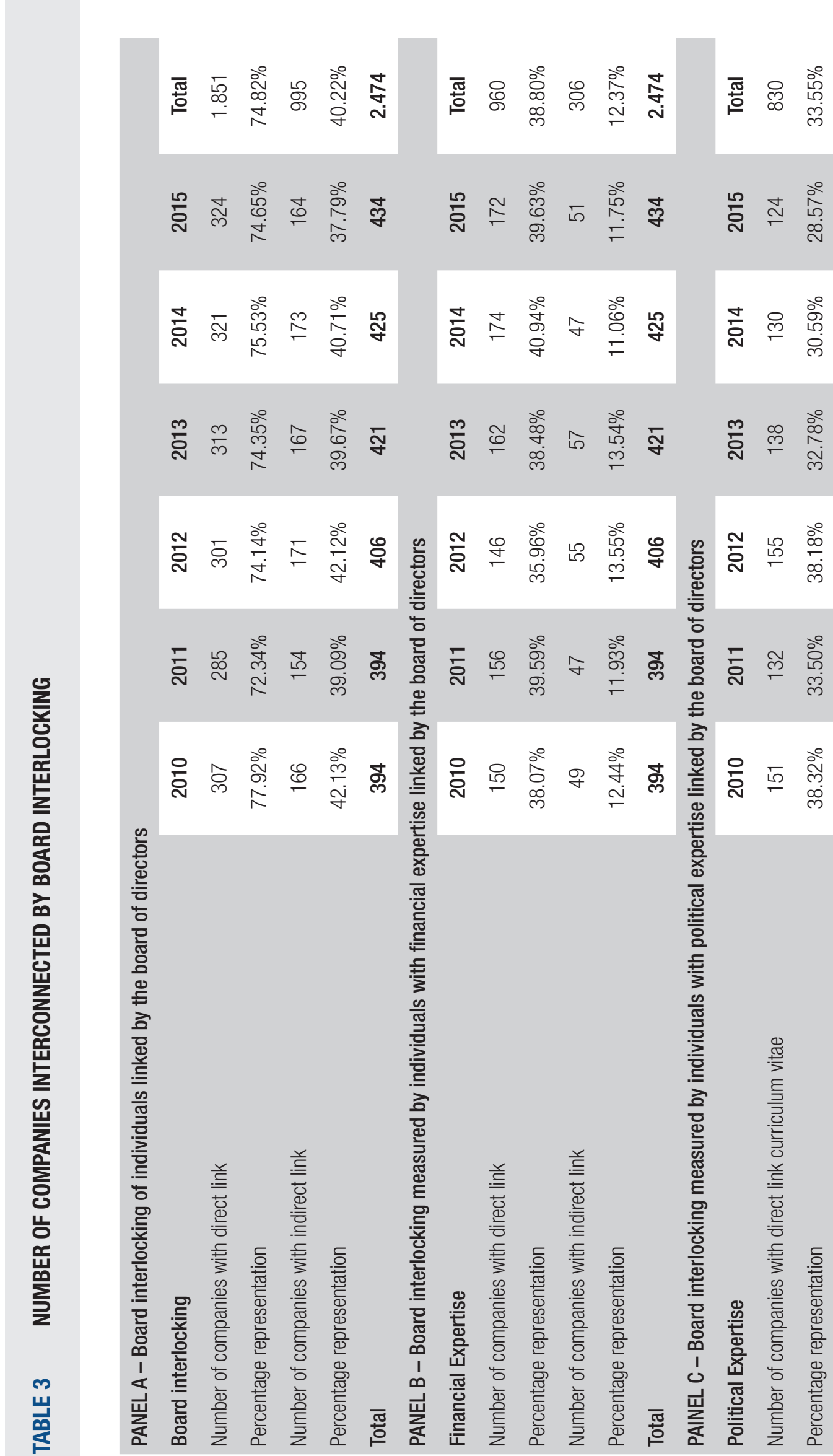

JOURnal of PUblic administration ｜ Rio de Janeiro 54(1):121-141, Jan. - Feb. 2020 
RAP | A new look at board interlocking: evidence from corporate social networks

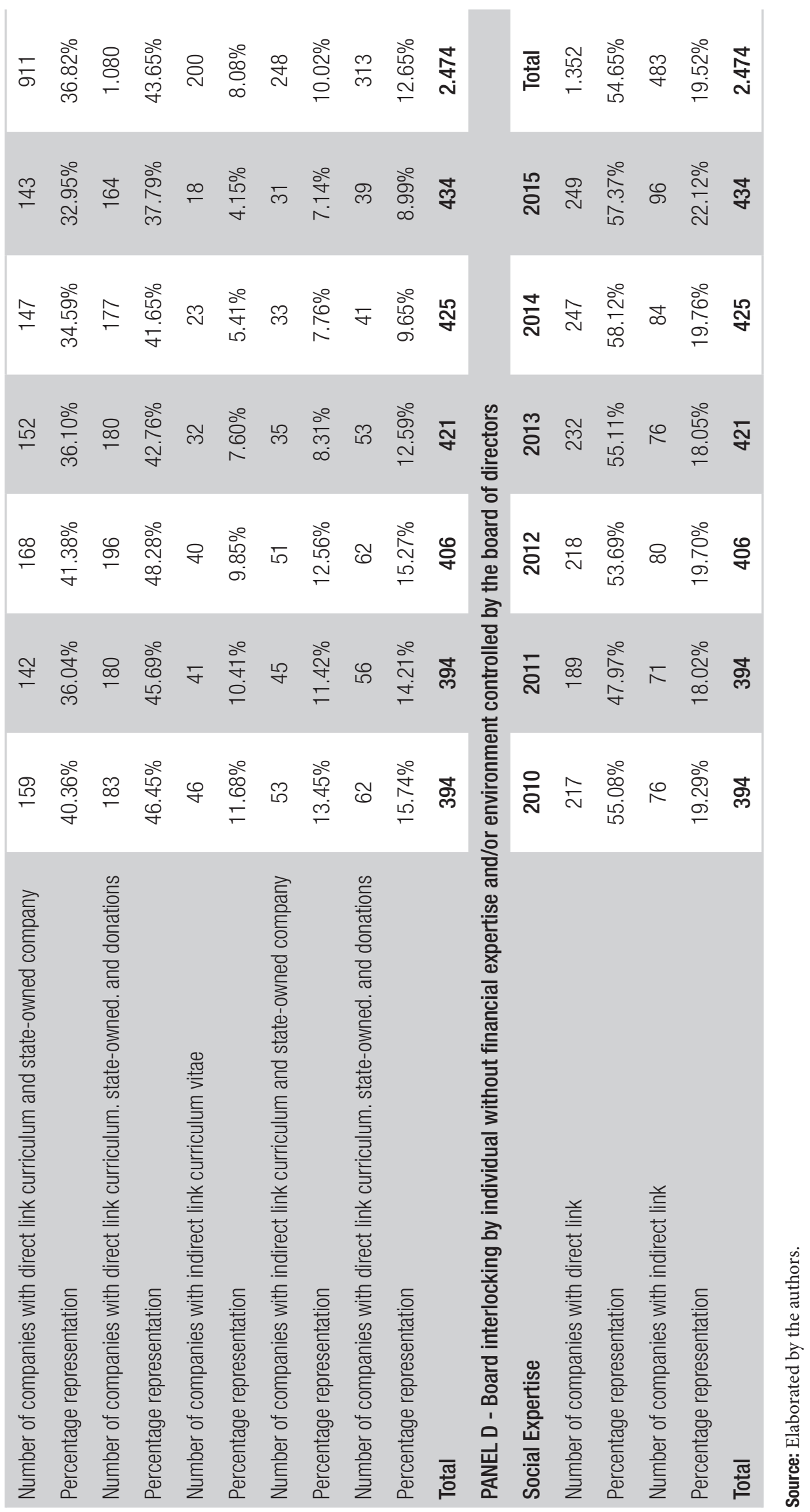

Journal OF Public administration ｜ Rio de Janeiro 54(1):121-141, Jan. - Feb. 2020 
Based on the findings, the conclusion is that a large proportion of companies had used members of financial institutions to form the board of directors, and they participate on several boards of directors of other companies. A large number of companies interconnected by members of financial institutions can explain a large number of Brazilian companies that use banks' financial capital even though they are in the stock market. The low rate of Brazilians willing to invest their resources in the stock market explains this, and therefore, companies listed on the stock market have to adhere to other financing forms.

Panel C presents the BI results measured by board members with political expertise who are linked directly or indirectly to the board of directors of other organizations. The identification of the political expertise was carried out in three steps a) a reading of the curriculum vitae of board members, observing those involved with political parties or who had held any political office, b) board members in state-owned companies were automatically considered as directors with political expertise and, c) board members who made donations for campaigns in the municipal elections of 2016.

Thus, the findings showed that, on average, $33.55 \%$ of direct BI links are made up of individuals who have political expertise, identified by reading their curriculum; $36.82 \%$ were board members in state-owned companies; and $43.65 \%$ were identified because they donated to the electoral campaign. In this regard, the findings indicate a reduction, from 2010 to 2015, in the number of companies with a direct or indirect connection of board members.

It is possible to say that the decline in the number of companies that compile their board of directors with members who have political expertise in the BI formation has become more evident in the years of 2013 and 2014. The period of turbulence in the Brazilian economy caused by the scandals among politicians, particularly the operation Car Wash (highlighted in mid-2014), could justify this result. Operation Car Wash resulted in successive arrests and accusations of financial benefits obtained by the political class, which may have resulted in the retraction of companies in incorporating politicians into their board of directors, as well as establishing BI connections with individuals who have political expertise.

Finally, Panel D shows the number of companies that have BI by direct or indirect link with board members who do not have financial or political expertise (average of $54.65 \%$ of companies). In the BI indirect links, only $19.52 \%$ of companies have links with members without financial and political expertise. This observation suggests that evaluating the effects of causality by the BI formation may have presented ambiguous results, considering that the BI formation is also represented by individuals with significant power, as occurs by financial and political institutions.

Table 4 presents the BI descriptive statistics by different expertise, the former segregated by the connections between the companies directors denominated BI only (LDBI and LIDI), according to previous studies (Cai et al., 2014; Chiu et al., 2013; Cunha \& Piccoli, 2017; Hashim \& Rahman, 2011; Ribeiro \& Colauto, 2016). The second is related to BI by social expertise (LDES and LIES), in which the study examine the exclusion of board members with political and financial expertise. In the third model we analyzed the board members with political expertise (LDEP and LIEP); the fourth model presents the analysis on political expertise and those belonging to state-owned 
companies (LDEPE and LIEPE); in the fifth models we analyzed members with political expertise, belonging to the state-owned companies and also those who donated to the campaign in the 2016 elections (LDEPED and LIEPED). The last model refers to the board members with financial expertise (LDEF and LIEF).

In Table 4, the centrality degree was calculated by the analysis of the direct connections formed by the social networks in each model of BI expertise. In order to do so, it was observed the mean density of the BI direct connections (LDBI) of 4.68. This result demonstrates that the companies analyzed presented a highly dense network of board members directly interconnected at the same time in several organizations.

In the $\mathrm{BI}$ direct links by social expertise (LDES) there is an average density of 3.59, lower than the LDBI, because, in this measurement model, companies with board interlocking that had members with political or financial expertise were excluded. It is inferred that the companies presented a highdensity network, showing a large proportion of companies directly linked by the board members without links with political and financial expertise. It is worthwhile to highlight that the direct link model by social expertise could be used by research that seeks to neutralize the effect of politicians and financial institutions.

\section{TABLE 4 DESCRIPTIVE STATISTICS OF THE DIRECT AND INDIRECT LINKS OF BI IN DIFFERENT EXPERTISE DURING THE YEARS 2010 TO 2015}

\begin{tabular}{|c|c|c|c|c|c|c|c|}
\hline \multicolumn{2}{|c|}{ Board Interlocking Variables } & $\mathrm{N}$ & Minimum & Maximum & Mean & Median & Standard \\
\hline \multicolumn{8}{|l|}{ Panel A } \\
\hline LDBI & Centrality (degree) & 2.474 & 0,00 & 24,00 & 4,68 & 3,00 & 2,94 \\
\hline LDES & Centrality (degree) & 2.474 & 0,00 & 17,00 & 3,59 & 3,00 & 2,30 \\
\hline LDEP & Centrality (degree) & 2.474 & 0,00 & 14,00 & 1,76 & 1,00 & 1,78 \\
\hline LDEPE & Centrality (degree) & 2.474 & 0,00 & 17,00 & 3,41 & 3,00 & 2,11 \\
\hline LDEPED & Centrality (degree) & 2.474 & 0,00 & 15,00 & 3,17 & 2,00 & 1,81 \\
\hline LDEF & Centrality (degree) & 2.474 & 0,00 & 16,00 & 3,65 & 3,00 & 2,21 \\
\hline \multicolumn{8}{|l|}{ Panel B } \\
\hline LIBI & Centrality (degree) & 2.474 & 0,00 & $7.939,03$ & 503,11 & 158,39 & 562,39 \\
\hline LIES & Centrality (degree) & 2.474 & 0,00 & $4.135,00$ & 522,75 & 144,58 & 555,37 \\
\hline LIEP & Centrality (degree) & 2.474 & 0,00 & 909,13 & 27,00 & 0,00 & 45,53 \\
\hline
\end{tabular}




\begin{tabular}{|llllllll}
\multicolumn{2}{l}{ Board Interlocking Variables } & N & Minimum & Maximum & Mean & Median & $\begin{array}{c}\text { Standard } \\
\text { Deviation }\end{array}$ \\
\hline LIEPE & Centrality (degree) & 2.474 & 0,00 & $2.821,62$ & 232,91 & 83,85 & 256,82 \\
\hline LIEPED & Centrality (degree) & 2.474 & 0,00 & $4.247,00$ & 393,63 & 122,00 & 424,26 \\
\hline LIEF & Centrality (degree) & 2.474 & 0,00 & $2.601,73$ & 334,01 & 113,38 & 353,86 \\
\hline
\end{tabular}

Source: Elaborated by the authors.

LDBI = direct board interlocking link; LIBI = indirect board interlocking link; LDES = direct link through social expertise; LIES = indirect link through social expertise; LDEP = direct link through political expertise; LIEP = indirect link through political expertise; LDEPE = direct link through political and state-owned expertise; LIEPE = indirect link through political and state-owned expertise; LDEPED = direct link through political, state-owned and campaign donation expertise; LIEPED = indirect link through political, state-owned and campaign donation expertise; LDEF = direct link through financial expertise; LIEF = indirect link through financial expertise.

Regarding the BI direct links by the political expertise (LDEP), the results indicate that the average density was 1.76. When board members of state-owned companies are included as those with political expertise, the average degree increases significantly (3.41). The same occurred when we included the board members of state-owned companies and the campaign donors as those with political expertise, indicating an average degree of 3.17 .

Finally, in the BI direct links by the financial expertise (LDEF), the average density was 3.65. The board members with political and financial expertise have high density in the companies analyzed, and it is possible to infer that there are interconnections among many companies by board members who have such expertise. The findings indicate that the network density of members with financial expertise is stronger than the one formed by political expertise. However, there is a greater proportion of members with political expertise interconnected in many companies.

The centrality (betweenness) was obtained by the analysis of indirect connections formed in the analysis of social networks considering each model of board interlocking expertise. Thus, the mean density of the BI indirect links (LIBI) was 503.11. For BI indirect links by social expertise (LIES), it was observed an average density of 522.75 .

Regarding BI indirect links by political expertise (LIEP), the results indicate that the average density was 27.00. In the indirect link by political expertise, considering the board members of state-owned companies, there is a significant increase in the average (betweenness) of 232.91, and when considered the board members who donated to the campaign in the 2016 elections, the average centrality increases to 392.63. Finally, in the BI indirect links by the financial expertise (LIEF), the average density was 334.01 . The findings indicate that, in direct links, there is a higher density for companies with political expertise compared to those with financial expertise. However, the result is the opposite when analyzing the centrality for indirect links.

The amplitudes of degree centralities are smaller than those obtained by the centralities of betweenness since the volume of direct connections is much smaller than the possibility of indirect connections between board members. Furthermore, direct linking forms an individual enterpriseto-enterprise network, while indirect-linking forms a dense network among multiple enterprises by the same individual. This amplitude becomes high because, as can be seen from the results in Table 3, 
there is a large proportion of board members who hold positions on the board of directors of several companies simultaneously.

The results suggest the hypothesis that large proportions of board members with different expertise can have significant effects on organizations' management. BI by political and financial expertise can interfere with business management decisions, given the proportion and density they present in the corporate social network.

In general, the study identified that the segregation of BI by the different expertise could present relevant information since the networks presented modifications based on the isolated observation of each BI expertise. The findings suggest that BI studies should emphasize the importance of observing the factors related to board of directors expertise. In this research, political and financial expertise and the isolated BI factor (social connection) were used. Future studies, however, may add new analysis factors.

\section{DISCUSSION AND CONCLUSIONS}

The research by Boubakri et al. (2008), Chaney et al. (2011), Camilo et al. (2012), Batta et al. (2014), Bona-Sánchez et al. (2014), and Braam et al. (2015) brought preliminary indications of the presence of politicians on companies' board of directors, as was the case with Güner et al. (2008) and Markarian and Parbonetti (2009), who indicated the broad participation of financial institutions on the board of directors of industrial companies. These factors have raised the concern of assessing the interconnection structure of these individuals in BI formation.

This research observed networks with different densities and connections when assessing the interconnection frameworks between board members from 2010 to 2015. This context may indicate that the companies involved in these networks have different results, as suggested in other studies.

Thus, the results indicate that $\mathrm{BI}$ is formed by individuals with different expertise. The findings confirm the participation of individuals linked to financial institutions on the board of directors of industrial organizations. The same happens with politicians, who are present on the board of private organizations, as well as simultaneously interconnected with other organizations directly and indirectly.

The results suggests that, in Brazil, BI measured by the systematics of corporate social networks, as applied by previous research (Chiu et al., 2013, Connelly \& Slyke, 2012, Cunha \& Piccoli, 2017, Elouaer-Mrizak \& Chaand, 2013; Fan, Guan, Li, \& Yang, 2014; Ribeiro \& Colauto, 2016; Santos et al., 2012; Wong et al., 2015) may not have captured the underlying interest of the links to the organizations' strategies, monitoring, and performance.

The results bring a reflection on misunderstandings in previous studies that generalized BI formation without considering the different expertise of board members. The contradictory findings of Chiu et al. (2013) and Mindzak (2013) may be a reflection of different BI measures. Fennema and Schijf (1978) and Bazerman and Schoorman (1983) have also criticized the generalized treatment of $\mathrm{BI}$, which offered limitations in determining corporate interference. In this sense, the segregation of BI by members with different expertise offers new analysis perspectives.

In general, these new perspectives will be useful to respond to the concerns of Burris (2005) and Santos et al. (2012), on the need to observe the purposes, cultures, experiences, and reasons that lead companies to establish the corporate bonds of the board of directors. The study contributes to

Journal OF Public administration | Rio de Janeiro 54(1):121-141, Jan. - Feb. 2020 
Burris (2005) by showing that future research can offer advances in the identification of the causes and effects of BI by different expertise.

The findings of this study suggest that BI structuring can help in future research that seeks to evaluate the diffusion of good or bad organizational practices. The results refer to the premise of Jensen and Meckling (1978) that agent behavior should be studied under the focus of the economic, sociological, and political model, enhancing explanations about certain corporate decisions.

Thus, the conclusion is that the BI by financial expertise could help broaden the sociological discussion of improvement of corporate monitoring and reduction of agency conflicts. On the other hand, it is possible to consider that the BI by political expertise could be used by researches that seek to observe agency conflicts and corporate monitoring costs.

The results indicate that the studies should broaden the discussions of agency theory by adding sociology to the economic reflection of Jensen and Meckling's (1976) preliminary concepts and, furthermore, jointly implementing the precepts of Jensen and Meckling (1978) seminal work. Therefore, Jensen and Meckling's $(1976,1978)$ studies are complementary and not isolated, as has been discussed by economic studies on agency theory.

This study also contributes to analyze the resources absorbed by the BI, depending on building of the expertise required, helping to expand the vision exposed by the resource dependence theory. The results allow the different expertise to be made available as a source of resources for organizations, such as those highlighted by the theory such as: a) reduction of uncertainties; b) guarantee of resources; c) access to new opportunities; and d) legitimacy.

In this sense, it was confirmed the wide dissemination of BI for financial expertise in companies and, therefore, the study suggests that it can serve as an opportunity for companies to obtain financial resources at attractive interest rates. Furthermore, BI by political expertise can be useful for companies to improve regulatory protection and establish new contractual arrangements with the government.

The systematization of BI by different expertise could be used by future research that seeks to observe the causes and consequences of BI formation of corporations. Therefore, it is suggested that BI for individuals with financial expertise can present different results from those with political expertise. It means that generalizing both phenomena in a single context can distort the corporate socialization view as a dissemination factor of corporate information and knowledge translated into results by resource dependence theory and in the corporate monitoring by agency theory.

The results of this research may be useful for financial institutions that evaluate the accounting information disclosed by the organizations for credit release, as well as for auditors, analysts, investors, and other stakeholders, who observe the different expertise in analyzing the BI effect in organizational behavior.

In several countries, such as Italy, Germany, and Brazil, legislation restricts, represses, and indicates possible interferences arising from BI formation. Therefore, the considerations point to opportunities for market regulators to increase reformulations of $\mathrm{BI}$ formation legislation.

One limitation of this study is that BI for the political expertise was measured by board members with political ties and also by former politicians and, therefore, future research that seeks to assess the effects of BI by political expertise in the organization's management should capture the possible effect of politicians in public office. Despite this, studies oppose the idea that ex-politicians will be 
individuals who occupy the advantages of their involvement with power (Boubakri et al., 2008; Camilo et al., 2012; Chaney et al., 2011; Faccio, 2006).

Recommendations for future research include looking at other expertise, such as academic background, professional experience, audit experience, which may be intrinsic among interconnected members of the board of directors and thus establish new BI expertise. In addition, it would be interesting to observe the argumentative capacity of the board members interconnected by the BI, as well as the gender of such individuals.

Furthermore, further studies need to capture the effects of holdings and those organizations that form a conglomeration of firms belonging to the same economic group. These factors can impact the BI formation by the board of directors of such companies and, consequently, offer results for research on the causality factors of BI formation. Thus, research that seeks to capture BI by different expertise and assess their causal effects on corporate practices, strategies, and performance needs to harness the effects of the holding, and controlled and associated firms.

Future studies need to reflect on the antecedents and consequences of the links: does the board of directors engage with the politics to promote the organization and defend regulatory interests? Or does the politician fit into the private environment to assist the government in defending its interests? It is important to reflect on the interests that lead the participation of board members with financial expertise in private companies, as well as their interconnection with the board of directors of other companies. It is necessary to a) understand the interest of the members with financial expertise in the board of directors decisions; b) assess what information is transferred by those members who participate simultaneously on the board of directors of several companies; and c) identify interference in corporate strategies. 


\section{REFERENCES}

Agrawal, A., \& Knoeber, C. R. (2001). Do some outside directors play a political role? The Journal of Law and Economics, 44(1), 179-198.

Aguilera, R. V., \& Jackson, G. (2010). Comparative and international corporate governance. The Academy of Management Annals, 4(1), 485-556.

Batta, G., Sucre Heredia, R., \& Weidenmier, M. (2014). Political connections and accounting quality under high expropriation risk. European Accounting Review, 23(4), 485-517.

Bazerman, M. H., \& Schoorman, F. D. (1983). A limited rationality model of interlocking directorates. Academy of Management Review, 8(2), 206-217.

Bizjak, J., Lemmon, M., \& Whitby, R. (2009). Option backdating and board interlocks. The Review of Financial Studies, 22(11), 4821-4847.

Bona-Sánchez, C., Pérez-Alemán, J., \& SantanaMartín, D. J. (2014). Politically connected firms and earnings informativeness in the controlling versus minority shareholders context: European evidence. Corporate Governance: An International Review, 22(4), 330-346.

Borgatti, S. P., \& Foster, P. C. (2003). The network paradigm in organizational research: a review and typology. Journal of Management, 29(6), 991-1013.

Boubakri, N., Cosset, J.-C., \& Saffar, W. (2008). Political connections of newly privatized firms. Journal of Corporate Finance, 14(5), 654-673.

Boubakri, N., Guedhami, O., Mishra, D., \& Saffar, W. (2012). Political connections and the cost of equity capital. Journal of Corporate Finance, 18(3), 541-559.

Bowen, R. M., Rajgopal, S., \& Venkatachalam, M. (2008). Accounting discretion, corporate governance, and firm performance. Contemporary Accounting Research, 25(2), 351-405.

Braam, G., Nandy, M., Weitzel, U., \& Lodh, S. (2015). Accrual-based and real earnings management and political connections. The International Journal of Accounting, 50(2), 111-141.

Burris, V. (2005). Interlocking directorates and political cohesion among corporate elites. American Journal of Sociology, 111(1), 249-283.
Byrd, D. T., \& Mizruchi, M. S. (2005). Bankers on the board and the debt ratio of firms. Journal of Corporate Finance, 11(1-2), 129-173.

Cai, Y., Dhaliwal, D. S., Kim, Y., \& Pan, C. (2014). Board interlocks and the diffusion of disclosure policy. Review of Accounting Studies, 19(3), 10861119.

Cai, Y., \& Sevilir, M. (2012). Board connections and M\&A transactions. Journal of Financial Economics, 103(2), 327-349.

Camilo, S. P. O., Marcon, R., \& Bandeira-de-Mello, R. (2012). Conexões políticas das firmas e seus efeitos na performance: uma convergência entre as perspectivas da governança e da dependência de recursos - um ensaio teórico. Revista Alcance, 19(2), 241-258.

Chaney, P. K., Faccio, M., \& Parsley, D. (2011). The quality of accounting information in politically connected firms. Journal of accounting and Economics, 51(1-2), 58-76.

Chiu, P.-C., Teoh, S. H., \& Tian, F. (2013). Board interlocks and earnings management contagion. The Accounting Review, 88(3), 915-944.

Connelly, B. L., \& Van Slyke, E. J. (2012). The power and peril of board interlocks. Business Horizons, 55(5), 403-408.

Cunha, P. R., \& Piccoli, M. R. (2017). Influência do board interlocking no gerenciamento de resultados. Revista Contabilidade \& Finanças, 28(74), 179-196.

Davis, G. F. (1991). Agents without principles? The spread of the poison pill through the intercorporate network. Administrative Science Quarterly, 36(4), 583-613.

Davis, G. F.., \& Mizruchi, M. S. (1999). The money center cannot hold: commercial banks in the US system of corporate governance. Administrative Science Quarterly, 44(2), 215-239.

D’Aveni, R. A., \& Kesner, I. F. (1993). Top managerial prestige, power and tender offer response: A study of elite social networks and target firm cooperation during takeovers. Organization science, 4(2), 123-151. 
Devos, E., Prevost, A., \& Puthenpurackal, J. (2009). Are interlocked directors effective monitors? Financial Management, 38(4), 861-887.

Dhaliwal, D. A. N., Naiker, V. I. C., \& Navissi, F. (2010). The association between accruals quality and the characteristics of accounting experts and mix of expertise on audit committees. Contemporary Accounting Research, 27(3), 787-827.

Eisenhardt, K. M., \& Schoonhoven, C. B. (1996). Resource-based view of strategic alliance formation: strategic and social effects in entrepreneurial firms. Organization Science, 7(2), 136-150.

Eleição Geral Federal 2018. (2018). Divulgação de candidaturas e contas eleitorais. Retrieved from http://divulgacandcontas.tse.jus.br/divulga/\#/

Elouaer-Mrizak, S., \& Chastand, M. (2013). Detecting communities within French intercorporate network. Procedia-Social and Behavioral Sciences, 79, 82-100.

Faccio, M. (2006). Politically connected firms. American Economic Review, 96(1), 369-386.

Fama, E. F., \& Jensen, M. C. (1983). Separation of ownership and control. The Journal of Law and Economics, 26(2), 301-325.

Fan, J. P. H., Guan, F., Li, Z., \& Yang, Y. G. (2014). Relationship networks and earnings informativeness: evidence from corruption cases. Journal of Business Finance \& Accounting, 41(7-8), 831-866.

Fennema, M., \& Schijf, H. (1978). Analysing interlocking directorates: theory and methods. Social Networks, 1(4), 297-332.

Fich, E. M., \& Shivdasani, A. (2006). Are busy boards effective monitors? The Journal of Finance, 61(2), 689-724.

Fich, E. M., \& White, L. J. (2005). Why do CEOs reciprocally sit on each other's boards? Journal of Corporate Finance, 11(1-2), 175-195.

Fligstein, N., \& Freeland, R. (1995). Theoretical and comparative perspectives on corporate organization. Annual Review of Sociology, 21(1), 21-43.

Galaskiewicz, J. (1985). Interorganizational relations. Annual Review of Sociology, 11(1), 281-304.
Galaskiewicz, J., \& Wasserman, S. (1989). Mimetic processes within an interorganizational field: an empirical test. Administrative Science Quarterly, 34(3), 454-479.

Gales, L. M., \& Kesner, I. F. (1994). An analysis of board of director size and composition in bankrupt organizations. Journal of Business Research, 30(3), 271-282.

Guedhami, O., Pittman, J. A., \& Saffar, W. (2014). Auditor choice in politically connected firms. Journal of Accounting Research, 52(1), 107-162.

Gulati, R., \& Westphal, J. D. (1999). Cooperative or controlling? The effects of CEO-board relations and the content of interlocks on the formation of joint ventures. Administrative Science Quarterly, 44(3), 473-506.

Güner, A. B., Malmendier, U., \& Tate, G. (2008). Financial expertise of directors. Journal of Financial Economics, 88(2), 323-354.

Haniffa, R. M., \& Cooke, T. E. (2002). Culture, corporate governance and disclosure in Malaysian corporations. Abacus, 38(3), 317-349.

Harris, D. A., \& Helfat, C. E. (2007). The board of directors as a social network: a new perspective. Journal of Management Inquiry, 16(3), 228-237.

Hashim, H. A., \& Rahman, M. S. A. (2011). Multiple board appointments: are directors effective? International Journal of Business and Social Science, 2(17), 137-143.

Haunschild, P. R. (1993). Interorganizational imitation: the impact of interlocks on corporate acquisition activity. Administrative Science Quarterly, 38(4), 564-592.

Hillman, A. J., Cannella, A. A., \& Paetzold, R. L. (2000). The resource dependence role of corporate directors: strategic adaptation of board composition in response to environmental change. Journal of Management Studies, 37(2), 235-256.

Hillman, A. J., \& Dalziel, T. (2003). Boards of directors and firm performance: integrating agency and resource dependence perspectives. Academy of Management Review, 28(3), 383-396.

Hillman, A. J., \& Hitt, M. A. (1999). Corporate political strategy formulation: a model of approach, 
participation, and strategy decisions. Academy of Management Review, 24(4), 825-842.

Hillman, A., \& Keim, G. (1995). Internationalvariation in the business-government interface: institutional and organizational considerations. Academy of Management Review, 20(1), 193-214.

Hoitash, U. (2011). Should independent board members with social ties to management disqualify themselves from serving on the board? Journal of Business Ethics, 99(3), 399-423.

Jensen, M. C., \& Meckling, W. H. (1976). Can the corporation survive? Rochester, NY: University of Rochester.

Jensen, M. C., \& Meckling, W. H. (1978). Can the corporation survive? Financial Analysts Journal, 34(1), 31-37.

Johnson, S., \& Mitton, T. (2003). Cronyism and capital controls: evidence from Malaysia. Journal of Financial Economics, 67(2), 351-382.

Kim, Y. (2005). Board network characteristics and firm performance in Korea. Corporate Governance: An International Review, 13(6), 800-808.

Kim, Y., \& Cannella, A. A., Jr. (2008). Toward a social capital theory of director selection. Corporate Governance: An International Review, 16(4), 282293.

Lei n. 13.165, de 29 de setembro de 2015. (2015). Altera as Leis n. 9.504, de 30 de setembro de 1997, 9.096, de 19 de setembro de 1995, e 4.737, de 15 de julho de 1965 - Código Eleitoral, para reduzir os custos das campanhas eleitorais, simplificar a administração dos Partidos Políticos e incentivar a participação feminina. Brasília, DF.

Loderer, C., \& Peyer, U. (2002). Board overlap, seat accumulation and share prices. European Financial Management, 8(2), 165-192.

Markarian, G., \& Parbonetti, A. (2009, April 28). Financial interlocks and earnings management: evidence from Italy. Retrieved from https://papers. ssrn.com/sol3/papers.cfm?abstract_id=1396299

Mizruchi, M. S. (1996). What do interlocks do? An analysis, critique, and assessment of research on interlocking directorates. Annual Review of Sociology, 22(1), 271-298.
Mindzak, J. (2013). Interlocked boards of directors, voluntary disclosures and earnings quality. Voluntary disclosures and earnings quality. In CAAA Annual Conference, School of Business Economics. Montreal, Canadá.

Mizruchi, M. S., \& Stearns, L. B. (1988). A longitudinal study of the formation of interlocking directorates. Administrative Science Quarterly, 33(2), 194-210.

Mol, M. J. (2001). Creating wealth through working with others: interorganizational relationships. Academy of Management Perspectives, 15(1), 150-152.

Okhmatovskiy, I. (2010). Performance implications of ties to the government and SOEs: a political embeddedness perspective. Journal of Management Studies, 47(6), 1020-1047.

Pearce, J. A., \& Zahra, S. A. (1992). Board composition from a strategic contingency perspective. Journal of Management Studies, 29(4), 411-438.

Pfeifer, H. (1972). Nuclear magnetic resonance and relaxation of molecules adsorbed on solids. In P. Diehl, E. Fluck, \& R. Kosfeld, NMR Basic Principles and Progress/NMR Grundlagen und Fortschritte (pp. 53-153). Berlin, Germany: Springer.

Ramanna, K., \& Roychowdhury, S. (2010). Elections and discretionary accruals: evidence from 2004. Journal of Accounting Research, 48(2), 445-475.

Ribeiro, F., \& Colauto, R. D. (2016). A relação entre board interlocking e as práticas de suavização de resultados. Revista Contabilidade \& Finanças, 27(70), 55-66.

Ryan, B., Scapens, R. W., \& Theobald, M. (2002). Research method \& methodology in finance \& accounting. London, England: Thomson.

Salancik, G. R., \& Pfeffer, J. (1978). A social information processing approach to job attitudes and task design. Administrative Science Quarterly, 23(2), 224-253.

Santos, R. L., Silveira, A. M., \& Barros, L. A. (2012). Board interlocking in Brazil: directors' participation in multiple companies and its effect on firm value and profitability. Latin American Business Review, 13(1), 1-28. 
Shropshire, C. (2010). The role of the interlocking director and board receptivity in the diffusion of practices. Academy of Management Review, 35(2), 246-264.

Shu, P.-G., Yeh, Y.-H., Chiu, S.-B., \& Yang, Y.-W. (2015). Board external connectedness and earnings management. Asia Pacific Management Review, 20(4), 265-274

Stearns, L. B., \& Mizruchi, M. S. (1993). Board composition and corporate financing: the impact of financial institution representation on borrowing. Academy of Management Journal, 36(3), 603-618.

Wasserman, S., \& Faust, K. (1994). Social network analysis: methods and applications. Cambridge, England: Cambridge University Press.

Wernerfelt, B. (1984). A resource-based view of the firm. Strategic Management Journal, 5(2), 171-180.

Wong, L. H. H., Gygax, A. F., \& Wang, P. (2015). Board interlocking network and the design of executive compensation packages. Social Networks, $41,85-100$

\section{Cristian Baú Dal Magro}

https://orcid.org/0000-0002-7609-5806

$\mathrm{PhD}$ in accounting and administration from Universidade Regional de Blumenau (FURB); Professor at Universidade Comunitária da Região de Chapecó (UNOCHAPECÓ). E-mail: crisbau@unochapeco.edu.br

\section{Roberto C. Klann}

https://orcid.org/0000-0002-3498-0938

$\mathrm{PhD}$ in accounting and administration from Universidade Regional de Blumenau (FURB); Professor at Universidade Regional de Blumenau (FURB). E-mail: rklan@furb.br 